\title{
Teletypewriters in Libraries: A State of the Art Report
}

\begin{abstract}
A literature survey was made of articles indexed in Library Literature and Library Science Abstracts which dealt with teletypewriter applications in all types of libraries. The survey is presented in a condensed form which summarizes and discusses dates of teletype installation, operations performed by these machines, and advantages and disadvantages accruing from their use. The most important findings of the survey were that libraries using teletypewriters employed them in six basic operations which contained thirteen inherent advantages, but that the paucity of reporting by libraries using teletypewriters greatly limits any true understanding of their importance.
\end{abstract}

$\mathrm{T}$ HE USE of the teletypewriter as a means of long distance communication between libraries is a subject about which little has been written. Many librarians are even ignorant of the fact that some libraries have used teletypewriters. Since 1927 at least 142 libraries in Europe and North America have, at some time, employed teletypewriters for data communication. What types of libraries use teletypewriters? In what capacities are these machines used, and what types of traffic pass over their circuits? What are the advantages and disadvantages librarians have found in using them?

In an attempt to answer these questions, a survey was made of library periodical literature. The results of the survey are presented here in a report which summarizes and comments on teletype operations in libraries as described in the literature since 1951, the first year in which an article on the subject appeared. Fewer than two score

Mr. Poole is Director of Libraries, Guilford College, Greensboro, North Carolina. articles have been published on this subject. Many of those were so barren of information that they could not be included here. Some evidence of the need for greater publishing efforts in this area can be understood when it is stated that the only criterion for inclusion in the present report was that an article say slightly more than "Library So and So has a teletypewriter." In fact, of the 142 libraries in Europe and North America using the teletypewriter, only fifteen have been reported on sufficiently to allow them to be included here.

In the summarized case studies of these fifteen libraries or library-related operations, the libraries have not been categorized, since this is obvious from their titles. They are however, divided by country. Dates of initial operation are supplied when they could be determined. Uses for and advantages accruing from the use of the teletypewriter are given, as are the references from which the information was taken. These references constitute the most comprehensive bibliography on this subject at the present time. 


\section{Summarized Case Studies of Fifteen \\ LIBRARY OR LIBRARY-RELATED \\ TELETyPe Operations}

\section{United States}

1. University of California libraries Installed: 1953

Operations: Interlibrary loan

General communication with libraries on other University of California campuses

Advantages: Speed

Reference: "Teletype Installation," UCLA Librarian, VI (August 14, 1953), 95.

2. Detroit public library

Installed: 1951 Discontinued: 1953 Operations: Reference services

Cooperative interlibrary loan network with Michigan State Library and its Extensions, Ryerson Public Library in Grand Rapids, and University of Michigan Library. Only the University of Michigan Library continues to operate a unit.

Advantages: Speed

\section{Increased resources}

Increased range of services Improved library cooperation

References: David Jolly, "The TWX in American Libraries," Libri, IV (1954), 302 307; Roy W. Schlinkert, "Detroit Urges Wider Use of Teletype," Library Journal, LXXVI (August 1951), 1190; "Teletype Service," Michigan Librarian, XVII (October 1951), 6 .

3. University of Kansas library

Installed: 1953

Operations: Cooperative interlibrary loan network with the Midwest InterLibrary Center and its member libraries Advantages: Speed

\section{Increased resources}

Reference: "Facts on the Double," Kansas Library Bulletin, XIII (March 1953), 9-10.

4. Lehigh University library

Installed: Not determined from literature

Operations: Interlibrary loan Requesting title locations from the Philadelphia Union Catalog
Advantages: Speed

Accuracy of a written message

Allows clarity in foreign language transmission without mispronunciation public relations

Prompt service enhances the telephone

Offers same flexibility as

Costs less than telephone

Reference: James D. Mack, "Teletype Speeds Interlibrary Loans and References," Library Journal, LXXXIII (May 1, 1958), 1325-29.

\section{Midwest Inter-Library Center}

Installed: 1953

Operations: Cooperative interlibrary loan network with member libraries. Only MILC continues to operate a unit. Advantages: Speed

References: Ralph T. Esterquest, "Teletype Network Problems," Midwest InterLibrary Center Newsletter, IV (July 31, 1953), 2; Jolly, loc.cit.; Mack, loc.cit.

6. Missouri state library

Installed: 1953

Operations: Cooperative interlibrary loan network with University of Missouri Library, Kansas City Public Library, St. Louis Public Library, and Linda Hall Special Library

Advantages: Speed

$$
\text { Increased resources }
$$

Reference: "TWX to Rescue of InterLibrary Loans," Show-Me Libraries, IX (October 1957), 4-5.

\section{New York state library}

Installed: 1958

Operations: Cooperative interlibrary loan network with seventeen other libraries in the state

Advantages: Speed

Simultaneous written record

Accuracy of a written message

Reference: W. P. Robinston, "TWX Lends New Wings to Interlibrary Loan and Reference Service," New York Library Association Bulletin, LIII (September 1960), 177-80. 
8. University of North Carolina library at Chapel Hill

Installed: 1958

Operations: Cooperative interlibrary loan network with North Carolina State Library

Providing title locations from North Carolina Union Catalog in Chapel Hill

Requesting title locations from the National Union Catalog at the Library of Congress

Advantages: Speed

Accuracy of a written message

Reference: "TWX in Operation," North Carolina Interlibrary Center News, VI (October-November 1958), 1.

9. Philadelphia free public library

Installed: 1927

Operations: Internal, closed-circuit communications for stack attendants

Advantages: Speed

Accuracy of a written message

Allows clarity in foreign language transmission without mispronunciation

Costs less than telephone

References: Jacques Bramhall, Jr., "Automation for the Reading Public," Office Executive, XXXV (May 1960), 18."Library Uses Teletypewriter," Journal of Business Education, XXXVI (October 1960), 25-26.

10. Philadelphia Union Catalog

Installed: 1957

Operations: Providing title locations

Advantages: Speed

Accuracy of a written message

Reference: Mack, loc.cit.

11. Racine public library

Installed: 1950

Operations: Cooperative interlibrary loan network with Milwaukee Public Library

Reference services

General communications

Advantages: Speed

Increased resources

Simultaneous written record
Increased range of services

Costs less than telephone

References: Esterquest, loc.cit.; Arthur Pethybridge, "RACMIL-TELETYPE," PLD Reporter, V (November 1956), 31-32; -, "RACMIL-Five Years Later," Library Journal, LXXIX (November 1, 1954), 2089-92; Stillman K. Taylor, A Survey of the Adult Department of the Racine Public Library, Racine, Wisconsin. Racine: The Library, 1952 , p. 16; Frederick Wezeman, "RACMIL, an Experiment in Library Cooperation," Libri, I (1951), 215-18.

12. U.S. Library of Congress

Installed: 1952

Operations: Communication with New York representative, Copyright Office, Office of the U.S. Quarterly Review, and publishers

Servicing title location requests to the National Union Catalog

Advantages: Speed

Efficiency

References: Esterquest, loc.cit.; U.S. Library of Congress, Information Bulletin, X (October 22, 1951), 11-12; ibid., XI (August 4, 1952), 8-9; ibid., XII (July 27, 1953), 12-13.

\section{Canada}

13. Toronto public libraries

Installed: 1962

Operations: Interlibrary loan Requesting title locations

Advantages: Speed

Reference: "Toronto Public Libraries Report a High Degree of Success with Telex," Wilson Library Bulletin, XXXVIII (October 1963), 126.

\section{Europe}

14. Manchester Central library (United Kingdom)

Installed: 1955

Operations: Interlibrary loan

lishers

Communication with pub-

Advantages: Speed

Simultaneous written record

Accuracy of a written message

Allows clarity in foreign 
language transmission without mispronunciation

Costs less than telephone

Can use codes and prepunched tapes to reduce toll costs

Provides automatic round-

the-clock answer service

References: "The Manchester Public Libraries: Telex Service," North West Newsletter, XXXV (September 1955), 11; Brian Rogerson, "Telex," Assistant Librarian, LIII (September 1960), 177-80.

15. Technical University library at Delft (Netherlands)

Installed: 1957

Operations: Interlibrary loan

Communication with publishers

Advantages: Speed

Accuracy of a written message

Costs less than telephone

Can use codes and pre-

punched tapes to reduce toll costs

References: G. Schuurmans Stekhoven, "The Linking of Libraries with the Aid of Teleprinters," Library Association Record, LXI (June 1959), 144-55; — , "InterLibrary Communications by Teleprinter," UNESCO Bulletin for Libraries, XII (August-September 1958), 216-17.

\section{Discussion}

While it is interesting to learn that libraries have been using teletypewriters since 1927, it will be more important to librarians considering installation of these machines to consider to what uses these machines are being put and what the advantages or disadvantages are in using them.

No pattern of use by academic, public, or special libraries ought to be defined, since fifteen libraries out of 142 hardly constitute a valid sample. The admixture of fifteen institutions in the present survey does show that all types of libraries make use of teletypewriters.

Though they may have been expressed in a variety of terms, the survey found that basically there were six applications of teletype in library situations. As could be expected, the application most often cited was that of interlibrary loans or of interlibrary-loan related operations. Ninety-three per cent of the available sample used their units in this capacity. Forty-six per cent of the units were used in cooperative networks designed to augment holdings on a reciprocal basis. Thirty-three per cent of the machines were used for general communications with other libraries or with publishing houses. Likewise, 33 per cent were used in some connection with union catalogs, either to request information or to supply it. Reference services were performed on 13 per cent of the units, and only 6 per cent were used for internal, closedcircuit communications.

Of the fifteen cases studied, and the thirteen advantages cited, 100 per cent indicated that speed of communication was the primary advantage in using a teletypewriter. Forty-six per cent reported that the accuracy of this type of communication was also of great advantage. Other advantages and their percentages were: costs below those of the telephone, 33 per cent; increased resources through cooperative networks, 26 per cent; clarity of foreign language transmissions, 20 per cent; the convenience of a simultaneous written record, 20 per cent; increased range of services to the public, 13 per cent; the ability to use codes and prepunched message tapes to reduce toll charges, 13 per cent; and improved library cooperation, public relations, and efficiency, each 6 per cent. A round-the-clock automatic answer service and a flexibility of communication equal to that of the telephone were also cited by 6 per cent of the sample.

Just what do these percentage figures tell us? First, it can be said that there is a direct relation between the advantage of speed and the application of the machine to interlibrary loans. The reason for this is quite plain to librarians with

(Continued on page 290) 
for rare book service. The Fellows have not emerged from the program as seasoned veterans, fully qualified rare book librarians, but they have had training not available elsewhere in such a relatively compressed period of time, and this training has given them a good start on the road to rare book librarianship. Indiana University had been the first to admit that its program was not well defined the first year, or the second or

\section{TELETYPEWRITERS . . .}

(Continued from page 286)

experience in interlibrary loans. Everyone wanting an interlibrary loan is in a hurry, and the quicker the library can supply the patron's needs, the happier the patron and the better the library image. In fact, for every use to which teletypewriters are put there are distinct, directly related advantages, as can be seen from a study of any individual case study in this report. The only disadvantage noted was that of cost caused by an increase in toll rates in the United States in 1953. This increase in rates caused several units to discontinue operation; such was the case of the Detroit public library.

Librarians considering the installation of a teletypewriter will naturally need to analyze the requirements of their particular libraries in order to determine which machine applications should be made and what advantages would accrue, and whether these advantages would justify the costs. For instance, in the case of a foreign library with much long distance or international traffic, the use of an optional accessory such as a tape perforator would be desirable, since one of the library's fundamental considerations would be methods of conserving toll costs, which leads to another point. Even in the fifteen existing case studies, little data on costs have been even the third. It was improvised as it proceeded. From this trial and error experience, however, sufficient information was gained to devise a more exacting program in the future. The experimental period financed by the Lilly Endowment expired with the end of the academic year 1963-64. It is hoped that the future will bring financing on a permanent basis.

published. It is an established fact that teletypewriter costs are lower than telephone tolls, but exact figures are difficult to find, and when found are usually out-of-date or invalid because of geographical peculiarities.

That fifteen libraries or library-related organizations have advantageously and successfully used teletypewriters since 1927 would indicate that this type of communication device is fairly well established in library operations. A recent census of the Teletypewriter Exchange Service (TWX) which appeared in Library Journal indicates that the use of this means of data communication is increasing. ${ }^{1}$

It is difficult to predict what the future holds for the teletypewriter and its functions as a library tool. Continued use in its present capacities is probably assured. Research is presently being done by at least one manufacturer in the area of computer and teletypewriter related applications. If these experiments prove to be successful, it could be that the automated libraries of the present and future will continue to find uses for the types of operations which the teletypewriter can perform.

\footnotetext{
${ }^{1}$ James D. Mack, "More Libraries Using Teletype for Interlibrary Loans," Library Journal, LXXXIX (December 15,1964$), 4880$.
} 